\title{
PILAR DO COMUNISMO OU ESCRITOR EXÓTICO? A RECEPČ̃̃ DOS ROMANCES DE JORGE AMADO NA POLÔNIA
}

\author{
Jaroslaw Jezdzikowski*
}

\begin{abstract}
RESUMO: Este artigo analisa as traduções dos romances de Jorge Amado na Polônia. Amado teve uma carreira notável em Polônia, tornando-se o escritor brasileiro mais traduzido no país. Sua obra começou a ser publicada na Polônia em 1949 e, até o fim do periodo do realismo socialista, em meados dos anos cinquenta, a obra do escritor baiano foi editada e reeditada com regularidade. As traduções da obra amadiana deixaram de ser editadas em 1958, retornando ao sistema literário polonês em 1968. No período seguinte, até 1993, as traduções passam a surgir com menos regularidade. $\mathrm{O}$ artigo examina a posição da obra amadiana dentro do sistema literário polonês, o uso político na parte do regime comunista da obra de Amado, e as próprias traduções em si.
\end{abstract}

UNITERMOS: Jorge Amado na Polônia; sistema literário polonês; traduções na Polônia; traduções durante stalinismo; traduções de Jorge Amado.

ABSTRACT: This article analyzes the translations of the novels of Jorge Amado made in Poland. Amado became very well-known in Poland and was the most-translated Brazilian author. His novels were first translated in 1949, and, until the end of the period of socialist realism, in the middle of the 1950s, translations of his works were frequently published and reprinted. Translations of his work stopped

\footnotetext{
* Universidade Federal da Bahia (UFBa), iarek@o2.pl
} 
being published in 1958, but they once again became part of the literary system in 1968. And until 1993 they were published, but with less frequency than in the previous period. This article examines the position of the work of Amado in the Polish literary system, the political use made of his work, and the translations themselves.

KEYWORDS: Jorge Amado in Poland; Polish literary system; translations in Poland; translations under Stalinism; translations of Jorge Amado.

\section{Introdução}

Jorge Amado teve uma carreira notável no sistema literário polonês, tornando-se o escritor brasileiro mais traduzido no país. Sua obra começou a ser publicada na Polônia em 1949 e, até o fim do período do realismo socialista, em meados dos anos cinquenta, a obra do escritor baiano foi editada e reeditada com regularidade. As traduções da obra amadiana deixaram de ser editadas em 1958, retornando ao sistema literário polonês em 1968. No período seguinte, até 1993, as traduções passam a surgir com menos regularidade.

A introdução das obras de Jorge Amado no polissistema sociocultural polonês acompanha um movimento maior de aceitação e de promoção da obra amadiana por parte do complexo mega-sistema soviético de literatura, que subentende os sistemas de literatura dos países-satélites da União Soviética. A trajetória particular do escritor e militante do partido comunista, que se encontrava exilado na Europa, vivendo na então Tchecoslováquia, contribui para esse enorme sucesso. Nos quatro anos de exílio, Amado viaja pelos países do bloco comunista e visita a Polônia seis vezes.

O sistema literário polonês, nacional e traduzido, está relacionado com os sistemas político, econômico, ideológico e linguístico que regem a dinâmica do polissistema sociocultural do país. Externamente, esse sistema entra em relação com outros sistemas literários, de modo especial, com as literaturas da União Soviética e das Democracias Populares, consideradas um siste-

TradTERm, 17, 2010, p. 127-156 
ma supranacional de literatura, assim como com os escritos dos autores comunistas de países fora desse bloco. Portanto, a análise das traduções polonesas da obra de Jorge Amado, apresentada neste artigo, contextualiza os textos traduzidos no ambiente dos sistemas político e literário da Republica Popular da Polônia.

\section{Política e literatura na Polônia Popular}

A Polônia, país localizado na Europa central - hoje com 38,6 milhões de habitantes, distribuídos nos 312.685 quilômetros quadrados do território nacional - entra na cena política, no final do século X. Um milênio da história é marcado pelo constante esforço dos poloneses para definir e afirmar a própria identidade - repetidas vezes - em resposta às invasões, na maioria dos casos, por parte de dois vizinhos mais fortes: os alemães no ocidente e os russos no oriente.

Na segunda metade do século XVIII, a Polônia perde a independência após três sucessivas anexações: à Áustria, à Prússia e à Rússia - que tomam para si porções do território polonês em 1772, 1793 e 1795, respectivamente - e praticamente desaparece do palco da história europeia por 150 anos. No final da primeira guerra mundial, em janeiro de 1918, o presidente norteamericano Thomas Woodrow Wilson reivindica a recriação do estado polonês, o que acontece em novembro de 1918.

Nos anos de 1918 a 1921, no período que antecedeu a consolidação do novo estado polonês, configuram-se duas tendências. Os partidos de esquerda, tendo menor apoio popular, buscam a realização dos interesses poloneses na aproximação com a União Soviética, chegando os comunistas a propor a transformação da Polônia em uma república soviética. Os partidos da direita, contando com a ampla simpatia da sociedade, defendem a incondicional independência da Polônia, trabalhando para o fortalecimento do nacionalismo polonês. Prevalecendo a tendência nacionalista, a Segunda República, nos anos 1919-1921, entra em conflito bélico com a União Soviética, paralelamente realizando negociações com a Alemanha e a Tchecoslováquia, no esforço de demarcar definitivamente as fronteiras. Em 1921, 
o território polonês estende-se por 388.600 quilômetros quadrados, com uma população de 27,2 milhões de pessoas. A política externa da Segunda República culmina em dois tratados de nãobeligerância: com a União Soviética, em julho de 1932, e com a Alemanha, em janeiro de 1934. Paralelamente, na politica interna, as forças governamentais perseguem a oposição de esquerda.

Depois do Anschluss da Áustria, em 1938, e da ocupação da República Tcheca no ano seguinte, Adolf Hitler, ciente da impotência dos aliados dos poloneses (Inglaterra e França), em 28 de abril de 1939 viola o Tratado de não-beligerância com a Polônia. Quatro meses depois, em 23 de agosto de 1939, os ministros do exterior da Alemanha, Joachim von Ribbentrop, e da União Soviéica, Viatcheslau Molotov, assinam em Moscou o Pacto de não-beligerância entre o Reich e a URSS. Além do compromisso de não-agressão entre os países pelo período de dez anos, o Pacto contém um protocolo adicional sobre a divisão da Europa central e oriental entre a Alemanha e a União Soviética. O documento conclui "o rearranjo das áreas pertencentes ao estado polonês em esferas de influência alemã e russa, seguindo a linha traçada pelos rios Narew, Wisła e San" (Davies, 1981: 433). O mencionado rearranjo do território polonês começa em primeiro de setembro de 1939, com a invasão da fronteira ocidental pelas tropas nazistas, e se intensifica com o ataque não-anunciado do Exército Vermelho à fronteira oriental, dezessete dias depois. Para subjugar o país conquistado, os dois agressores abafam todas as expressões da cultura polonesa nos territórios invadidos. Os intelectuais são perseguidos e entram na clandestinidade, fogem para fora do país e morrem nos campos de concentração alemães e russos. As universidades e as escolas de ensino médio são fechadas. Os nazistas alemães pretendem transformar os povos eslavos na força de trabalho barata a serviço do Übermensch do Terceiro Reich. Os soviéticos aniquilam a intelectualidade polonesa para assim facilitar o controle das massas e a introdução da ditadura do proletariado.

O acordo selado entre dois sistemas totalitários logo é rompido. Hitler viola o Pacto assinado em Moscou e invade a Rússia em 22 de junho de 1941. Depois da derrota dos nazistas em Stalingrado, tem início uma sucessão de conquistas militares 
da contra-ofensiva do Exército Vermelho. Esta mudança no campo de batalha provoca a mudança na política externa da União Soviética. Na primavera de 1941, Stalin funda a escola de marxismo-leninismo para preparar os militantes do partido comunista polonês, dependente do Kremlin. O PC prepara a representação política que vai assumir o governo na Polônia. A União dos Patriotas Poloneses, criada em Moscou pelos comunistas poloneses e controlada por Stalin, assume a logística da retomada do poder na Polônia.

A criação do governo polonês, composto de pessoas controladas por Stalin, em 20 de julho de 1944, em Moscou, oferece a garantia da fidelidade ao aliado maior. O governo provisório, chamado de Comitê de Libertação Nacional, depois de assinar em Moscou o tratado sobre as fronteiras, no qual cede à URSS uma parte do território, entra na Polônia com o exército soviético. Dois dias depois da criação do governo provisório, a Rádio Moscou emite, em língua polonesa, o texto do Manifesto do Comitê da Libertação. O Manifesto, redigido em Moscou e revisto por Stalin, sugere que o Comitê de Libertação, como continuação legítima do governo polonês, exija a total libertação da Polônia. A integridade das fronteiras da Polônia está assegurada por meio da aliança com a URSS.

Na segunda metade de 1944, no território polonês, ainda em guerra contra o exército fascista, aguça-se o conflito entre as forças militares dirigidas pelo Governo Polonês, exilado em Londres desde 1939, e as forças armadas polonesas e soviéticas que apóiam o Comitê de Libertação Nacional. Um dos momentos mais críticos do início desta guerra civil é o levante de Varsóvia, promovido em Londres, no momento em que os nazistas já se encontram na defensiva e o Exército Vermelho se aproxima de Varsóvia. O Governo no Exílio pretende libertar a capital com as suas próprias forças e, desta maneira, ganhar a posição mais forte na discussão sobre a composição do futuro governo polonês. Pelos mesmos motivos, o Comitê de Libertação detém-se com o Exército Vermelho nas margens do rio Wisła, nos arredores de Varsóvia, esperando o desenvolvimento da situação.

O levante termina em 2 de outubro de 1944, com o massacre dos rebeldes. Como sinal da morte da resistência, a cidade 
de Varsóvia é sistematicamente destruída pelos nazistas. Zélia Gattai (1987: 77-78) descreve suas impressões da capital polonesa, quatro anos após do levante:

Apenas uma parte do Hotel Bristol, o único de Varsóvia, onde nos hospedamos, ficara de pé. A outra fora destruída, queimada. Sentia-se ainda no quarto um longínquo cheiro de fumaça. Varsóvia era só ruínas. Pelas ruas transitavam aleijados, mutilados da guerra, tantos como nunca eu imaginava ver: gente de muletas, sem braços, sem pernas, sem olhos, rostos deformados... Todos eles atarefados, dando sua contribuição na remoção dos entulhos, num trabalho sem fim. Após o levante geral, em 1944, morreram 200 mil poloneses.

Esmagado o levante, o Exército Vermelho começa a ofensiva sobre Varsóvia, cruza o rio Wisła e entra na cidade no início de janeiro de 1945. Em breve, o Comitê de Libertação assume o controle de todo o país. Em 19 de janeiro de 1945, o Governo em Londres dissolve todas as suas forças armadas na Polônia. Uma parte desse exército, porém, permanece na clandestinidade e organiza gupos guerrilheiros para lutar contra a invasão do exército soviético. Para combater a resistência polonesa, o Comitê de Libertação usa as forças armadas dependentes do Comitê de Politica Interior soviético. O conflito se agrava e travam-se combates regulares. Os dirigentes da resistência são presos, julgados em Moscou em junho de 1945 e condenados à prisão. A guerra civil continua até 1948 .

Nas eleições para o parlamento constituinte, em 19 de janeiro de 1947, com 80\% de votos, vence o Bloco Democrático, composto pelo Partido Operário e pelo Partido Socialista. O parlamento elege o presidente e o primeiro ministro, que assume a missão de compor o governo. Os principais personagens da política polonesa são impostos e controlados por Moscou. O presidente eleito, Bolesław Bierut, partidário da rápida stalinização da Polônia, foi escolhido para ocupar o lugar de destaque na política polonesa pelo próprio Stalin. O ministro da defesa, o marechal soviético Konstanty Rokossowski, assume o comando do exército polonês a partir de 1949 .

TradTerm, 17, 2010, p. 127-156 
Em dezembro de 1948, entra em fase de execução na Polônia o plano de unificação de todo o movimento operário, incentivado por Stalin em todo o bloco comunista. A criação do novo Partido Operário Unificado Polonês consolida a hegemonia do stalinismo no país. Depois das eleições de 1947, o presidente Bierut organiza e chefia o grupo que prepara a nova constituição. Bierut apresenta a Stalin o projeto de constituição, traduzido para o russo no outono de 1951. O projeto volta de Moscou com 82 correções, feitas a lápis por Stalin. As correções do líder soviético são introduzidas no texto da nova Carta Magna, votada em 22 de julho de 1952. A lei fundamental declara a Polônia democracia popular e república do povo operário, intervenção de Stalin na primeira frase do Preâmbulo, o que limita os direitos das classes que até então viviam da exploração do operário e do camponês. Neste sistema político monopartidário, o partido Operário Unificado Polonês torna-se a garantia e o guardião da nova ordem democrática. O país muda o nome para República Popular da Polônia, e o cargo de Presidente é abolido. A constituição de 1952 sanciona a sovietização da Polônia para as próximas quatro décadas.

A stalinização da vida política forneceu as bases para o controle total de todas as formas de vida pública e privada, assim como para a total dependência da Polônia das diretrizes elaboradas pela cúpula do PC soviético. Na República Popular, o sistema político penetra em todas as atividades do cidadão: no plano econômico e cultural, na vida social e no exercício da individualidade. No regime comunista, os imperativos da política fizeram da literatura uma ferramenta ideológica da propaganda, como bem observa Steven Pinker (2004: 221-222). O mecenato do Estado subvenciona a produção da literatura e concede aos escritores um elevado status social, exigindo deles, em contrapartida, a observância dos ditames ideológicos e poéticos em vigor. Com o tempo, os escritores tutelados pelo regime reivindicam liberdade para a criação literária. Seus patrões respondem com o aumento da censura. Desta maneira, a literatura polonesa permanece presa aos construtos ideológicos do comunismo.

Para que um sistema literário possa manter-se estável, é preciso que ele esteja em comunicação com os sistemas literários de outros polissistemas socioculturais. O intercâmbio entre 
os sistemas por meio da tradução contribui para o enriquecimento do repertório oferecido dentro de um determinado sistema literário e para a criação de alternativas para os seus modelos já consagrados. Segundo Itamar Even-Zohar (1990:25-26), somente um sistema literário altamente heterogêneo, isto é, aquele que possui um repertório bastante variado, tem a capacidade de manter-se estável sem recorrer aos novos modelos fornecidos pela tradução.

Depois da decretação do dirigismo estético no ano de 1949, o sistema literário da Polônia oferece ao público leitor um volume insuficiente de obras literárias, tanto do ponto de vista da quantidade de livros editados, como também do ponto de vista da diversidade de modelos literários. De fato, para os comunistas, a vida cultural começa na Polônia em 1944. De acordo com essa posição, a literatura polonesa está vivendo seus momentos primordiais. Para enriquecer a oferta, o sistema literário polonês recorre à tradução. As obras a serem traduzidas são escolhidas segundo critérios políticos. Importando os textos escritos nos países das Democracias Populares, o sistema literário polonês proporciona um ambiente que valoriza a tradução. A insuficiência do próprio sistema literário, nas palavras de Clem Robyns (1994: 420), permite ver a importação dos textos como um fato enriquecedor para o sistema, gerando desta maneira, um discurso positivo sobre a tradução.

A partir de 1949, no decorrer do processo de perseguição contra os dirigentes dos partidos comunistas, Stalin descobre também na política polonesa o chamado desvio nacionalista. Este fato provoca desconfiança diante da produção literária polonesa da época, que, supostamente, instiga posturas nacionalistas. Nessa situação, a política editorial polonesa recorre à tradução de obras soviéticas. A política tradutória do stalinismo demonstra uma clara preferência pela literatura soviética da atualidade e pela literatura dos países que integram o bloco soviético. Traduzem-se e editam-se, principalmente, as obras atuais do realismo socialista. Contudo, também as obras clássicas dos países do bloco entram no sistema literário polonês.

Paralelamente ao aumento do número de textos traduzidos das línguas do bloco soviético, o número de títulos da litera- 
tura ocidental contemporânea, traduzidos para o polonês, diminui drasticamente. Para o sistema literário polonês, a Cortina de Ferro significa o fechamento da literatura polonesa às tendências ideologicamente incorretas das literaturas ocidentais. $\mathrm{Na}$ época do realismo socialista traduzem-se, exclusivamente, os escritores progressistas, isto é, os comunistas e os simpatizantes, denominados criptocomunistas. Nessa época, a tradução manipulada com fins políticos iniciada pelo regime comunista introduz no sistema literário polonês o escritor brasileiro Jorge Amado.

\section{Importação de Jorge Amado para o sistema literário polonês}

Jorge Amado entra no sistema literário polonês como um escritor consagrado pelo público leitor no Brasil e no estrangeiro, com mais de dez livros publicados no país de origem, além de traduções para o espanhol, russo, francês e inglês. Na União Soviética, os romances Cacau e Suor são conhecidos desde 1935, publicados um ano depois da decretação do dirigismo estético na URSS, em 1934. A imprensa polonesa apresenta o escritor como um militante experiente do Partido Comunista, que já havia sofrido várias prisões no Brasil e cujos livros tinham sido proibidos pela censura, apreendidos nas livrarias e até queimados na cidade de Salvador. Em sua militância, o escritor baiano ganhou o mandato de deputado federal nas eleições de 1945. Em janeiro de 1948, seu mandato é anulado em decorrência do decreto de ilegalidade do $\mathrm{PCB}$. O militante do partido comunista parte em exílio para Paris, fugindo do Brasil mais uma vez. Em setembro de 1949, Amado é expulso da França com a família por motivos politicos e passa a residir na então Tchecoslováquia, retornando ao Brasil em maio de 1952.

A projeção do escritor brasileiro nas Democracias Populares começa no período de exílio na Europa. Amado viaja intensamente pelos países do bloco soviético, participando de eventos literários e reuniões partidárias. Nessas viagens, o escritor reúne um grande grupo de amigos influentes, dentre eles personalidades da vida cultural e política dos países do bloco soviético, 
fato assinalado nas dedicatórias de ambos os livros escritos neste período. No final dos anos quarenta, a obra de Jorge Amado é traduzida para as línguas dos paises integrantes do bloco soviético, consequentemente, também para o polonês. Um dos critérios da edição de traduções na época do stalinismo é a comparação com o sistema literário soviético. Se a obra funciona na URSS, pode ser introduzida no sistema nacional, e se o autor é editado sem restrições na URSS, pode ser editado no sistema nacional. O Prêmio Stalin Internacional da Paz, concedido ao romancista brasileiro em 20 de dezembro de 1951, abre irrestritamente o mega-sistema literário do bloco soviético para o escritor. O prestígio do Prêmio Stalin, equivalente no bloco soviético ao prestígio do Prêmio Nobel, consagra o autor e canoniza sua obra no sistema literário das Democracias Populares.

Com referência ao sistema literário polonês, a produção de Jorge Amado, no período em que o escritor vive na Tchecoslováquia, caracteriza-se pela alta canonicidade. Nesta época surge $O$ mundo da paz, editado na Polônia no ano de 1954, um relato das viagens feitas pela União Soviética e pelas Democracias Populares, um trabalho que se enquadra no gênero das reportagens produzidas na Polônia com a finalidade de engrandecer as conquistas soviéticas. A intenção do autor, expressa na epígrafe, de rebater as calúnias divulgadas pela imprensa capitalista sobre os países do bloco, corresponde perfeitamente aos ditames da propaganda polonesa. Editado na Polônia no ano de 1953, Os subterrâneos da Liberdade, um relato histórico da luta dos comunistas brasileiros contra o imperialismo, coloca em primeiro plano o retrato do herói novo, um militante comunista, construindo um mundo melhor. Este perfil harmoniza-se perfeitamente com o herói novo postulado pela literatura polonesa da época. As duas obras são traduzidas imediatamente e logo editadas na Polônia.

A obra de Jorge Amado presente no sistema literário polonês compreende 17 traduções, entre romances, biografias e diários de viagem, editadas e reeditadas, separadamente ou em conjunto, num total de 26 edições. Entre o ano de 1949 e 1957, são traduzidas 11 obras, editadas e reeditadas em 20 edições. Entre o ano de 1968 e 1993, são traduzidas 6 obras, editadas e reeditadas em 6 edições.

TradTerm, 17, 2010, p. 127-156 
A tabela a seguir apresenta a distribuição das traduções da obra amadiana na Polônia entre os anos de 1949 e 1993.

Tabela 1. A distribuição das traduções da obra amadiana nos anos de 1949 a 1993

\begin{tabular}{|c|c|c|c|c|}
\hline Ano & Título em polonês & Título em português & Tradutores & Editora \\
\hline 1949 & $\begin{array}{l}\text { Kakao } \\
\text { Świt Brazylii (Kakao; Pot) } \\
\text { Rycerz Nadziei } \\
\text { Ziemia krwi i przemocy }\end{array}$ & $\begin{array}{l}\text { Cacau } \\
\text { Cacau e Suor } \\
\text { O cavaleiro da esperança } \\
\text { Terras do sem fim }\end{array}$ & $\begin{array}{l}\text { Hołyńska; Gruda } \\
\text { Hołyńska; Gruda } \\
\text { Hołyńska; Gruda } \\
\text { Wrzoskowa }\end{array}$ & $\begin{array}{l}\text { Czytelnik } \\
\text { Czytelnik } \\
\text { Czytelnik } \\
\text { Czytelnik }\end{array}$ \\
\hline 1950 & $\begin{array}{l}\text { Jubiaba } \\
\text { Ziemia złotych płodów } \\
\text { Drogi głodu } \\
\text { Albania radosna }\end{array}$ & $\begin{array}{l}\text { Jubiabá } \\
\text { São Jorge dos Ilhéus } \\
\text { Seara Vermelha } \\
\text { A Albânia é uma festa }\end{array}$ & $\begin{array}{l}\text { Hołyńska; Gruda } \\
\text { Wrzoskowa } \\
\text { Hołyńska; Gruda } \\
\text { Hołyńska; Gruda }\end{array}$ & $\begin{array}{l}\text { Czytelnik } \\
\text { Czytelnik } \\
\text { Czytelnik } \\
\text { Czytelnik }\end{array}$ \\
\hline 1951 & $\begin{array}{l}\text { Zamarte morze } \\
\text { Rycerz Nadziei } \\
\text { Drogi głodu }\end{array}$ & $\begin{array}{l}\text { Mar morto } \\
\text { O cavaleiro da esperança } \\
\text { Seara Vermelha }\end{array}$ & $\begin{array}{l}\text { Hołyńska; Gruda } \\
\text { Hołyńska; Gruda } \\
\text { Hołyńska; Gruda }\end{array}$ & $\begin{array}{l}\text { Czytelnik } \\
\text { Czytelnik } \\
\text { Czytelnik } \\
\end{array}$ \\
\hline 1952 & Świt Brazylii (Kakao; Pot) & Cacau e Suor & Hołyńska; Gruda & Czytelnik \\
\hline 1953 & $\begin{array}{l}\text { Zamarte morze } \\
\text { Ziemia krwi i przemocy } \\
\text { Ziemia złotych płodów } \\
\text { Podziemia wolności }\end{array}$ & $\begin{array}{l}\text { Mar morto } \\
\text { Terras do sem fim } \\
\text { São Jorge dos Ilhéus } \\
\text { Os subterrâneos da liberdade }\end{array}$ & $\begin{array}{l}\text { Hołyńska; Gruda } \\
\text { Wrzoskowa } \\
\text { Wrzoskowa } \\
\text { Hołyńska; Gruda }\end{array}$ & $\begin{array}{l}\text { Czytelnik } \\
\text { Czytelnik } \\
\text { Czytelnik } \\
\text { Czytelnik }\end{array}$ \\
\hline 1954 & $\begin{array}{l}\text { Drogi gtodu } \\
\text { Świat pokoju }\end{array}$ & $\begin{array}{l}\text { Seara Vermelha } \\
\text { O mundo da paz }\end{array}$ & $\begin{array}{l}\text { Hołyńska; Gruda } \\
\text { Hołyńska; Gruda }\end{array}$ & $\begin{array}{l}\text { Czytelnik } \\
\text { PIW }\end{array}$ \\
\hline 1956 & Kakao & Cacau & Hołyńska; Gruda & Czytelnik \\
\hline 1957 & Opowieść o Castro Alvesie & $A B C$ de Castro Alves & Hołyńska; Gruda & PIW \\
\hline 1968 & Gabriela & Gabriela cravo e canela & Wrzoskowa & $\mathrm{KiW}$ \\
\hline 1972 & $\begin{array}{l}\text { Gabriela } \\
\text { (Starzy marynarze: } \\
\text { Podwójna śmierć Kuby Wodowstręta) }\end{array}$ & $\begin{array}{l}\text { Gabriela cravo e canela } \\
\text { Os velhos marinheiros: } \\
\text { (O capitão de longo curso; } \\
\text { Quincas Berro D'água) }\end{array}$ & $\begin{array}{l}\text { Wrzoskowa } \\
\text { Wrzoskowa; } \\
\text { Gruda }\end{array}$ & KiW \\
\hline 1975 & Pasterze nocy & Os pastores da noite & Wrzoskowa & KiW \\
\hline 1989 & Tereza Batista wojowaniem zmęczona & Teresa Batista cansada de guerra & Reis & WL \\
\hline 1993 & Dona Flor i jej dwóch mężów & Dona Flor e seus dois maridos & Lenczewska & WL \\
\hline
\end{tabular}

Legenda: PIW: Państwowy Instytut Wydawniczy (Instituto Editorial do Estado); KiW: Książka i Wiedza (Livro e Conhecimento) WL: Wydawnictwo Literackie (Editora Literária)

A Tabela 1 ilustra o interesse dos dirigentes do polissistema sociocultural polonês pela tradução da obra de Jorge Amado, no período de 1949 a 1957 . Na história do país, este é um momento em que o recém-instalado regime comunista busca a legitimação perante a sociedade polonesa. A importação dos textos de escritores comunistas, entre eles, os romances de Jorge Amado para o sistema literário polonês, deve reforçar uma visão 
do mundo que caminha rumo ao comunismo universal. A ausência de traduções do escritor brasileiro nos anos de 1958 a 1967 corresponde ao período da história do país em que o regime comunista encontra-se firme no poder. Concluindo que o regime não precisa mais de legitimação urgente por parte dos produtores culturais, os chefes do PC polonês decidem cortar os subsídios para a cultura.

A Tabela 1 apresenta a volta das traduções da obra amadiana nas três décadas que se seguem. Nos anos setenta, no sistema literário polonês, é lançada uma série de traduções de literatura latino-americana em fascículos chamados Prosa ibero-americana. Stanisław Siekierski (1992: 268-272) fala de uma clara preferência da política editorial polonesa pela tradução desse tipo de literatura. Um grande número de autores lançados no quadro da série Prosa ibero-americana passou pela militância comunista ou simpatizava com os movimentos esquerdistas. Sendo assim, autores como Amado perfazem o perfil do escritor comprometido com a esquerda, disseminado pelos dirigentes do polissistema literário polonês na época do socialismo real. A moda de dos autores latino-americanos, lançada pelos leitores profissionais e propagada pela imprensa especializada, foi bem recebida nos meios intelectuais e acadêmicos. A pesquisa da receptividade mostra, porém, que o interesse por este tipo de literatura nunca atingiu um público maior e não conquistou os leitores no meio operário e rural.

Paralelamente aos lançamentos de livros traduzidos, a imprensa polonesa publica tanto fragmentos dos romances do autor brasileiro quanto romances inteiros em episódios. Esta prática é comum nos anos de 1948 a 1953, quando são publicados 11 fragmentos dos romances amadianos. No período posterior, essas publicações ocorrem três vezes. O romance mais publicado pela imprensa é Terras do sem fim. A primeira publicação de um fragmento deste romance, na tradução de Maria Borowska se dá ainda no ano de 1948, isto é, um ano antes da publicação do livro, traduzido por Janina Wrzoskowa. Terras do sem fim também foi publicado em episódios, nos anos 1949-1950 pelos jornais locais. A última publicação de um fragmento desse romance ocorre em 1980. Da mesma forma, os fragmentos de $\mathrm{Ca}$ -

TradTerm, 17, 2010, p. 127-156 
cau, Jubiabá, O cavaleiro da Esperança, O mundo da Paz, e Seara Vermelha são publicados pela imprensa. A tradução polonesa de Cacau é lida, em fragmentos, na rádio nacional, no decorrer do ano de 1949, todas as segundas-feiras, a partir do dia 24 de janeiro. No ano de 1962, publica-se, em episódios, A morte e a morte de Quincas Berro D'água na tradução de Eugeniusz Gruda. O conto De como o mulato Porciúncula descarregou seu defunto é publicado em 1975 na tradução de Halina Czajka.

\section{Aspectos macroestruturais das traduções polonesas}

Do total de 26 edições das obras do escritor brasileiro presentes no sistema literário polonês, optou-se pela escolha de um exemplar de cada obra traduzida para o polonês. Apesar da disponibilidade de exemplares de todas as edições nas bibliotecas polonesas, não foi possivel adquirir a totalidade das 26 edições no mercado polonês. Portanto, a facilidade de acesso às traduções de Jorge Amado no mercado editorial polonês no ano de 2005 constituiu o princípio para a escolha dos exemplares para análise. Para fins de comparação, para cada tradução polonesa buscou-se um texto amadiano editado no Brasil. Desta maneira, o corpus da pesquisa é formado por 17 volumes apresentados pela tabela a seguir. 
Tabela 2. O corpus para a análise das traduções polonesas da obra de Jorge Amado

A Tabela 2 apresenta as fontes textuais na ordem cronológica que acompanha o aparecimento dos textos no Brasil. Com isso não se pretende hierarquizar os textos, nem privilegiar a cronologia das edições brasileiras em detrimento da cronologia das traduções polonesas. Este procedimento visa oferecer uma

TradTerm, 17, 2010, p. 127-156

\begin{tabular}{|c|}
\hline $\begin{array}{l}\text { Título } \mathrm{Pl} \text { vertido } \\
\text { para } \mathrm{Br}\end{array}$ \\
\hline Сасаи \\
\hline Aurora do Brasil \\
\hline Jubiabá \\
\hline Mar parado \\
\hline $\begin{array}{l}\text { O conto sobre } \\
\text { Castro Alves }\end{array}$ \\
\hline $\begin{array}{l}\text { O cavaleiro da } \\
\text { esperança }\end{array}$ \\
\hline $\begin{array}{l}\text { Terra do sangue e } \\
\text { da violência }\end{array}$ \\
\hline $\begin{array}{l}\text { Terra de frutos } \\
\text { dourados }\end{array}$ \\
\hline Caminhos da fome \\
\hline A Albânia alegre \\
\hline O mundo da paz \\
\hline $\begin{array}{l}\text { Os subterrâneos } \\
\text { da liberdade }\end{array}$ \\
\hline Gabriela \\
\hline $\begin{array}{l}\text { Os velhos } \\
\text { marinheiros }\end{array}$ \\
\hline $\begin{array}{l}\text { Os pastores da } \\
\text { noite }\end{array}$ \\
\hline $\begin{array}{l}\text { Dona Flor e seus } \\
\text { dois maridos }\end{array}$ \\
\hline $\begin{array}{l}\text { Tereza Batista } \\
\text { cansada de } \\
\text { guerrear }\end{array}$ \\
\hline
\end{tabular}


informação adicional sobre a política editorial do sistema literário polonês, que escolhe os textos amadianos a serem traduzidos e editados no país. A tabela evidencia o fato de que duas traduções polonesas são publicadas antes das respectivas edições brasileiras. Trata-se, em ambos os casos, de textos escritos na época em que Jorge Amado vive na Tchecoslováquia, circulando nos países do bloco soviético.

Observando os dados da Tabela 2, podem-se perceber as prioridades do sistema literário polonês com respeito à obra amadiana. Nos anos de 1949 a 1957, na Polônia, traduziu-se quase a totalidade de sua obra publicada até então, com exceção dos romances, País do carnaval e Capitães da areia, do guia Bahia de Todos os Santos e da peça teatral O amor do soldado. Nos anos de 1968 a 1993, apenas seis obras de Jorge Amado são traduzidas para o polonês. Analisando a Tabela 2, chama a atenção o fato de que quase todos os romances amadianos escritos entre os anos de 1958 a 1972 tenham sido escolhidos para a tradução, com exceção de $A$ Tenda dos milagres, romance nunca publicado no mercado polonês. As traduções de Gabriela cravo e canela, Os velhos marinheiros e Os pastores da noite são lançados nos anos de 1968 a 1975, isto é, num período de tempo relativamente curto. As traduções de Tereza Batista cansada de guerra (de 1989) e de Dona Flor e seus dois maridos (de 1993) são lançadas mais de duas décadas depois, no fim do regime comunista e início da democratização do país. Nenhuma das obras amadianas escritas depois de 1972 entrou, por meio de tradução, no sistema literário polonês.

Observando os títulos das traduções, chega-se à conclusão de que eles sofrem manipulação no período de 1949 a 1957. A edição conjunta das traduções de Cacau e Suor, intitulada Aurora do Brasil, não traz na capa os títulos dos respectivos romances. Quando editado separadamente, Cacau funciona como um título independente no sistema literário polonês. O mesmo não acontece com Suor, apresentado nas capas de ambas as edições sob o título de Aurora do Brasil. Os termos "aurora" ou "alvorada" são comumente usados pelo mega-sistema cultural soviético no período do realismo socialista. Esses termos expressam a noção de um começo instaurado pela revolução do pro- 
letariado, assim como representam simbolicamente o começo da revolução de 1917 na Rússia, iniciado pelo disparo do navio de guerra bolchevique "Aurora" contra o Palácio do Inverno em Petersburgo. Nessa época, de modo especial, o título dado ao volume de várias obras editadas em conjunto traz a chave para a interpretação dos textos reunidos no tomo. Neste sentido, Aurora do Brasil pode sugerir ao leitor polonês o início do processo revolucionário pelo movimento operário brasileiro.

A tradução manipulou os títulos de Mar Morto e de $A B C$ de Castro Alves. No caso do primeiro romance, o título polonês foge da possibilidade de interpretação no sentido geográfico (o lago salgado nos territórios de Israel e Jordânia) e sugere a noção de paralisação ou de suspensão do movimento. No caso do segundo romance, o gênero literário de um abecedário - desconhecido na Polônia - foi substituído pelo gênero de conto ou de narrativa sobre a vida do personagem. Os títulos de Terras do sem fim, de São Jorge dos Ilhéus e de Seara Vermelha foram alterados pela tradução. A tradução polonesa do título de Terras do sem fim para Terra do sangue e da violência acompanha as escolhas da tradução inglesa de 1945 e da tradução francesa de 1946, que fazem menção à "terra violenta". A tradução polonesa do título de São Jorge dos Ithéus para Terra de frutos dourados acompanha as escolhas da tradução francesa de 1947 e da tradução russa de 1948, assim como das traduções búlgaras, eslovaca e tcheca, todas de 1950. A tradução polonesa do título Seara vermelha para Caminhos da fome acompanha a escolha da tradução francesa de 1949. É significativa a constatação de que os títulos das traduções polonesas lançadas entre os anos de 1949 a 1957 trazem para o público polonês um significado familiar e fácil de entender. A exceção constitui o romance Jubiabá, introduzindo um termo estrangeiro que só pode ser entendido como um nome após a leitura de parte do romance.

A partir de 1972, as edições polonesas não manipulam mais os títulos brasileiros, introduzindo até empréstimos do português brasileiro para a língua polonesa, como em Tereza Batista e Dona Flor. Em ambos os casos, os titulos das traduções usam a grafia original dos nomes, o que reforça no leitor a sensação de se tratar de obras estrangeiras. Os nomes de "Ba-

TradTerm, 17, 2010, p. 127-156 
tista" e de "Flor" soam estranho em polonês. Embora exista em polonês o nome "Teresa", na tradução optou-se por "Tereza". Da mesma maneira, em vez de traduzir o pronome de tratamento para "Pani", comum na Polônia, o título conserva o estrangeirismo "Dona".

Desta forma, no total dos 17 itens do corpus, os títulos de 6 romances são manipulados pela tradução. Todas essas ocorrências acontecem no periodo do realismo socialista. Três títulos introduzem estrangeirismos no idioma polonês. Por se tratar de um personagem histórico, o nome do poeta Castro Alves é reproduzido em sua forma original.

Alguns títulos de capítulos e subseções foram modificados pela tradução polonesa. Os exemplos mais significativos para a análise são apresentados na tabela a seguir.

Tabela 3. Títulos dos capítulos e subseções

\begin{tabular}{|c|c|c|}
\hline Título & Capítulo $\mathrm{PI}$ vertido para $\mathrm{Br}$ & Capítulo Br \\
\hline \multirow[t]{2}{*}{ Cacau } & Fruta chamada Jaca & Jaca \\
\hline & Festa & Acarajé \\
\hline \multirow[t]{2}{*}{ Suor } & Intrusos & Gringos \\
\hline & Sentidos & Sexo \\
\hline \multirow[t]{2}{*}{ Jubiabá } & Boxeador & Lutador \\
\hline & Marinheiro & Hans, o marinheiro \\
\hline A Albânia é uma festa & Crianças dormem nas creches & As crianças dormindo \\
\hline \multirow{3}{*}{ O Mundo da paz } & Defesa da paz & Impor a paz \\
\hline & Popularização da cultura & Democratização da cultura \\
\hline & Escritores-operários discutem & Escritores e operários discutem \\
\hline \multirow{3}{*}{ Gabriela cravo e canela } & Encanto de Gabriela & O luar de Gabriela \\
\hline & Caçada ao homem & Da grande caçada \\
\hline & Tristeza de Gabriela & Suspiros de Gabriela \\
\hline \multirow[t]{2}{*}{$O$ capitão de longo curso } & ... desembargador em négligé & ... desembargador em ceroulas \\
\hline & ... um navio da Companhia Ita & ... um Ita \\
\hline
\end{tabular}

A Tabela 3 demonstra que a edição abreviada de Cacau traz os títulos dos capítulos para mais perto da realidade do leitor polonês, explicando ou evitando os marcos culturais. Esse procedimento torna-se inteligivel no contexto de um lançamento destinado para leitores novatos. 
A edição polonesa do romance Suor demonstra duas tendências na tradução dos capítulos. A tradução evita a referência à sexualidade (Sentidos) e agrava a expressão usada para denominar o estranho, utilizando um termo carregado pelo juízo de valor (Intrusos). Essas tendências estão de acordo com a ideologia vigente na época, que dessexualiza os personagens literários e hostiliza os cidadãos do bloco capitalista.

A tradução de Jubiabá explana o título brasileiro de "Lutador", especificando que se trata de um lutador de boxe. De acordo com a ideologia vigente, a tradução omite uma possivel menção aos alemães.

As traduções de A Albânia é uma festa e de $O$ mundo da paz manipulam os títulos dos capítulos de acordo com as necessidades políticas do regime da Polônia. A tradução do título "As crianças dormindo" acrescenta o dado sobre as creches. Na realidade polonesa, o discurso sobre a emancipação das mulheres e sua ascensão profissional inclui a campanha em favor das creches, tratadas com certo preconceito pela mulher polonesa. O discurso sobre a paz, na perspectiva do regime polonês, é um discurso em favor da manutenção de um bem já conquistado. $\mathrm{O}$ título traduzido expressa essa posição quando fala em defesa da paz. Por sua vez, na ótica do título brasileiro, que fala em imposição, a paz é um bem a ser conquistado. A tradução evita os termos carregados de significado no cotidiano polonês. As constantes reivindicações da população pela democratização do regime são recebidas pelos comunistas como uma tentativa de contrarrevolução. A ditadura do proletariado não abre espaço para o discurso sobre a democratização. Por isso, a tradução de $O$ Mundo da paz traz o termo de "popularização", ao invés de falar em "democratização". O título brasileiro sugere um diálogo entre os escritores e os operários. A tradução fala em discussão promovida por ou entre os escritores-operários. De acordo com a política cultural vigente, a estratégia da criação de novas elites intelectuais na Polônia contava com os escritores vindos do meio operário. A menção dos escritores-operários pode refletir essa tendência.

A tradução dos títulos do romance Gabriela cravo e canela demonstra a tendência para enfatizar as características ou o 
estado de humor da protagonista, falando no encanto ou na tristeza de Gabriela. A explicitação, de cunho sensacionalista, na tradução do título "Caçada ao homem" visa prender a atenção do público leitor para o fato extraordinário de uma caçada ao ser humano.

Finalmente, no romance A completa verdade sobre as discutidas aventuras do comandante Vasco Moscoso de Aragão, capitão de longo curso, a tradução apresenta uma tendência para explicitar os marcos culturais brasileiros para o leitor polonês. O título do texto-fonte traz o termo "Ita" como a designação comum das embarcações da Companhia Nacional de Navegação Costeira, e é traduzido para o polonês como o "navio da Companhia Ita". No mesmo texto, a menção da peça de roupa intima masculina recebe na tradução um termo provindo da língua francesa, que parece menos deselegante do que a designação polonesa da roupa de baixo masculina. A tradução dos títulos dos capítulos de outros romances não apresenta maiores modificações.

A Tabela 4 apresenta os dados referentes à tiragem e aos preços das traduções.

\begin{tabular}{|c|c|c|c|c|}
\hline Título & $1 \mathrm{Ang}$ & TiTinagem & eprecen & bascículos \\
\hline Terras do sem fim & 1949 & 50.500 & -- & não \\
\hline Jubiabá & 1950 & 15.400 & 370,0 & $\operatorname{sim}$ \\
\hline São Jorge dos Ilhéus & 1950 & 20.400 & 450,0 & $\operatorname{sim}$ \\
\hline Seara vermelha & 1950 & 20.400 & 300,0 & não \\
\hline A Albânia é uma festa & 1950 & 15.350 & 80,0 & não \\
\hline Mar morto & 1951 & 8.350 & -- & não \\
\hline O cavaleiro da esperança & 1951 & 75.570 & 2,4 & $\operatorname{sim}$ \\
\hline Aurora do Brasil (Cacau+Suor) & 1952 & 7.140 & 11,0 & não \\
\hline Os subterrâneos da liberdade & 1953 & 10.160 & 41,0 & não \\
\hline O mundo da paz & 1954 & 7.175 & 11,0 & $\operatorname{sim}$ \\
\hline Cacau & 1956 & 20.205 & 4,0 & $\operatorname{sim}$ \\
\hline ABC de Castro Alves & 1957 & 5.205 & 10,0 & não \\
\hline Gabriela cravo e canela & 1972 & 10.260 & 35,0 & não \\
\hline Os velhos marinheiros & 1972 & 20.000 & 25,0 & não \\
\hline Os pastores da noite & 1975 & 25.350 & 35,0 & não \\
\hline Tereza Batista cansada de guerra & 1989 & 15.350 & $1.950,0$ & $\operatorname{sim}$ \\
\hline Dona Flor e seus dois maridos & 1993 & -- & -- & não \\
\hline
\end{tabular}


A média das tiragens de prosa literária nos anos cinquenta perfaz 14 mil exemplares. No mesmo período, as obras dos clássicos do marxismo são lançadas com a tiragem média de 35 mil. Os anos sessenta demonstram uma tendência decrescente, e a média das tiragens passa a $11 \mathrm{mil}$. Na época, diminui a produção editorial, mas a média das tiragens cresce nos anos setenta, alcançando 13 mil exemplares. Nos anos oitenta, essa média totaliza 25 mil. Embora os valores médios não elucidem com exatidão os mecanismos da política editorial, podem ser úteis para indicar certas tendências.

A análise da Tabela 4 permite formular a opinião de que, nos anos cinquenta e nos anos setenta, as tiragens das traduções ultrapassam as respectivas médias. No período do realismo socialista, chamam a atenção as tiragens enormes de $O$ cavaleiro da Esperança (50 500 exemplares na primeira edição) e de Terras do sem fim (75 570 exemplares na segunda edição), que colocam o autor no patamar dos clássicos do marxismo. O lançamento de $O$ cavaleiro da esperança e de Cacau, com tiragens grandes e com o preço evidentemente barato, demonstra o interesse dos dirigentes do sistema pelas obras amadianas e, também, a maneira como o sistema faz uso de lançamentos em fascículos para popularizar a literatura ideologicamente aproveitável.

As tiragens acima da média, nos anos setenta, acompanham a tendência dos leitores profissionais pela literatura latino-americana e servem, possivelmente, para a popularização desses escritos junto ao público leitor. No caso de Gabriela cravo e canela, trata-se da segunda edição (a primeira teve a tiragem de 20 mil). A tiragem de Tereza Batista cansada de guerra, abaixo da média nos anos oitenta, sugere um público-alvo seleto e restrito, interessado na série Literatura ibero-americana. O exemplar de Dona Flor e seus dois maridos não oferece dados sobre a tiragem. A informação referente à tiragem - nas décadas passadas um instrumento de controle obrigatório - não constitui mais uma exigência desde 1990.

Nos anos de 1949 a 1993, editaram-se na Polônia mais de 450 mil exemplares de traduções da obra de Jorge Amado, sem levar em conta a tradução de Dona Flor e seus dois maridos, cuja tiragem não foi divulgada. Nos anos de 1949 a 1957, foram lan-

TradTerm, 17, 2010, p. 127-156 
çados no mercado polonês cerca de 400 mil exemplares. Nos anos de 1968 a 1993, o mercado polonês absorveu, aproximadamente, 100 mil exemplares.

Uma grande parte da produção editorial, desde a época do stalinismo, abastece a rede de bibliotecas, fixas e móveis, em todo o território do país. A conferência das fichas dos usuários das bibliotecas permite estabelecer as prioridades entre os leitores poloneses no ano de 1956. No item literatura contemporânea não soviética figura a obra de Jorge Amado, Terras do sem fim, como um romance bastante requisitado. A análise das fichas nas bibliotecas demonstra ainda que alguns autores estrangeiros, entre eles os latino-americanos, lançados nas décadas seguintes e amplamente comentados na imprensa especializada e nos jornais, atingiram o público leitor nos maiores centros culturais do país.

A análise macroestrutural das traduções polonesas da obra de Jorge Amado permite constatar o interesse do sistema literário polonês pela produção literária do escritor brasileiro. Essa opção é manifesta pelo número de obras traduzidas, sua tiragem grande e o preço acessivel, bem como pelo volume de metatextos que acompanharam o lançamento das traduções. O sistema literário polonês tem interesse em apresentar os livros editados como traduções, divulgando o nome do autor estrangeiro nas capas e as informações sobre a tradução e os tradutores nas folhas de rosto. A estrutura física das traduções, das capas, dos títulos e das notas explicativas, demonstra uma clara tendência de aproximar o universo da criação amadiana do público leitor polonês.

\section{Aspectos microestruturais das traduções polonesas}

Os resultados da análise macroestrutural do corpus apontam claramente para o fato de que o sistema literário polonês tende a manipular as traduções da obra de Jorge Amado para adequá-las às exigências do polissistema sociopolitico da República Popular da Polônia. A tendência de intervir nas traduções é muito forte no período stalinista, decresce nas décadas de setenta e oitenta, desaparecendo depois da queda do regime comunista. 
Para viabilizar a análise microestrutural, todos os textos que compõem o corpus foram lidos, linha por linha, primeiro na tradução polonesa e, em seguida, em português, como sugere a metodologia descritiva (Lambert, Van Gorp 1985; Toury 1995). A primeira seleção das sequências (polonês - português) estabeleceu um número em torno de 800 pares de ocorrências, classificadas, em seguida, em seis categorias que, no decorrer da leitura, mostraram-se dominantes na tradução da obra de Jorge Amado. O estabelecimento das categorias a posteriori atendeu as exigências do estudo empírico. A delimitação das categorias, que resultou da ordenação do material obtido durante a análise do corpus, compreendeu os domínios de termos culturalmente marcados pelo onomástico e pela culinária, pela moral, pelos relacionamentos, pela religião, pela categoria do hostilizado e pelas soluções secundárias.

Numa segunda seleção, onde isso se mostrou viável, para todas as categorias foram selecionadas sequências provenientes de cada um dos textos que integram o corpus. O texto traduzido para o polonês foi vertido para o português e apresentado ao lado do texto-fonte. Esse cotejo de textos - traduzido (TA), versão $\mathrm{Br}$, e português (TF) - permite uma compreensão fácil dos procedimentos tradutórios adotados. A contextualização dos procedimentos tradutórios no âmbito do polissistema sociopolítico da Polônia permitiu delinear as normas que regeram a tradução da obra de Jorge Amado para o idioma polonês.

A categoria da moral, apresentada em seguida, mostra um dos exemplos do espaço ideológico de grande interesse para o regime da Republica Popular. O regime comunista elabora os padrões comportamentais para a sociedade polonesa nos primeiros anos após a tomada de poder. A moral comunista que dita os tabus e também cria os valores positivos, transfere para o campo da arte a discussão sobre o etos do homem novo. Com sua função educacional, a literatura constitui um espaço privilegiado para esse debate.

Os resultados da análise do corpus permitem a constatação de que as traduções polonesas das obras de Jorge Amado sofrem forte influência dos ditames da moral em vigor. A primeira questão moral que chama a atenção nos textos traduzidos é o 
discurso sobre a sexualidade do menor de idade, como demonstram os exemplos a seguir.

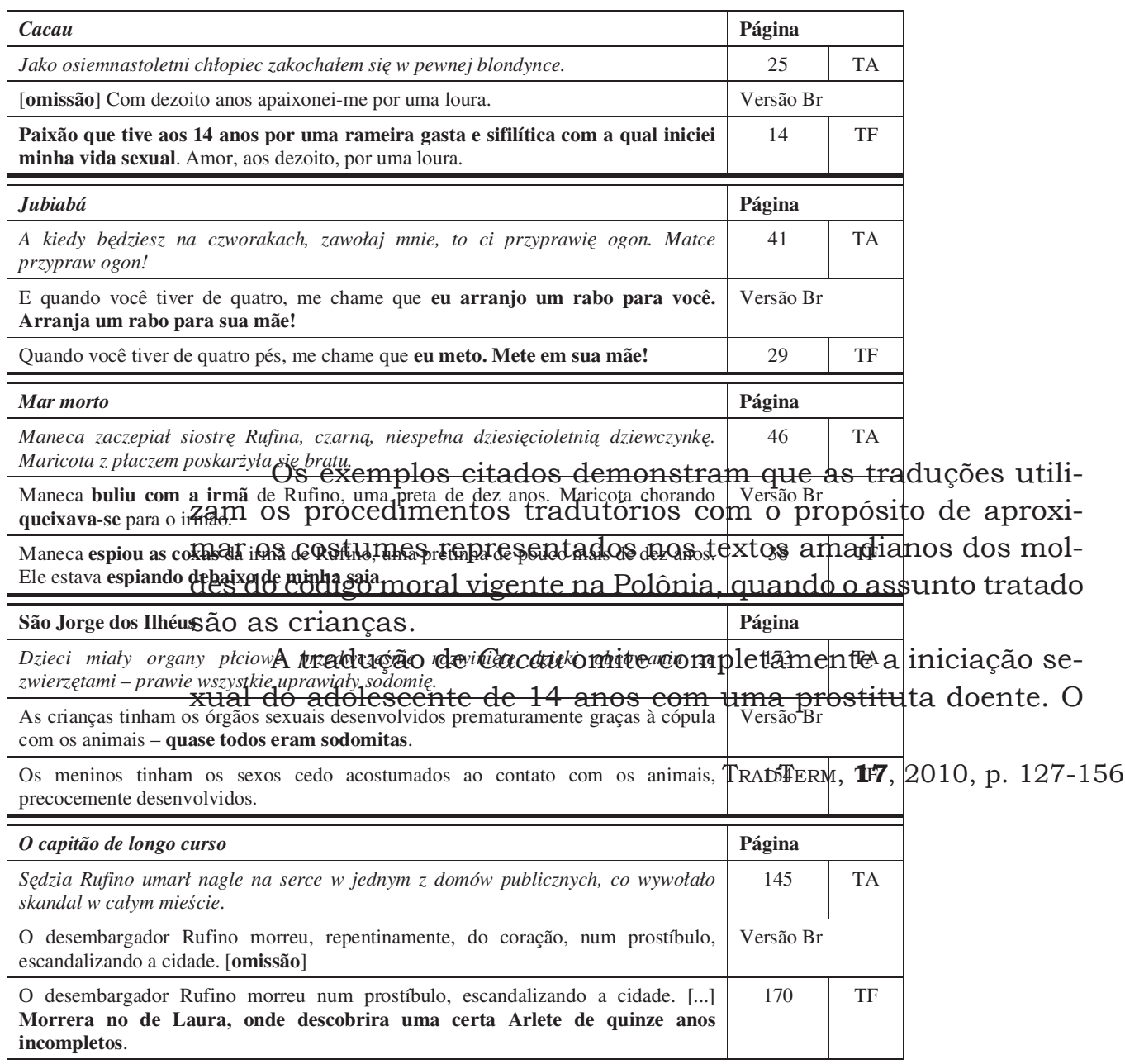


texto polonês retoma a narração do personagem a partir dos 18 anos, a idade que marca a entrada na vida de adulto, e portanto, o início de sua atividade sexual. A omissão ocorre na tradução de Jubiabá quando o texto-fonte faz menção à relação homossexual entre os meninos e a uma relação incestuosa com a própria mãe.

Em Mar morto, Maneca, um adolescente de 14 anos abusa da menina de 10 anos de idade. O texto polonês registra o desentendimento entre as crianças (o menino buliu com a menina), mas omite a natureza sexual do acontecimento. Na mesma linha de raciocínio, a menção da prostituição infantil e da pedofilia é omitida na tradução de $O$ capitão de longo curso.

Já em São Jorge dos Ilhéus, a tradução fala em zoofilia erótica ou bestialidade praticada por menores de idade. Sem omitir o fato narrado no TF, a tradução qualifica o ocorrido como caso de sodomia. O uso da linguagem científica para denominar essa prática indica que a tradução não está interessada em apresentar o fato em si, mas amenizá-lo com a tentativa de classificação teórica do ato. Também, por meio desta adição, a tradução classifica o comportamento referido como anormal.

As representações da sexualidade dos adultos estão submetidas, na tradução polonesa, aos ditames da moral comunista, como indicam os exemplos. 


\begin{tabular}{|c|c|c|c|}
\hline Gusqualeiro da esperança & \multicolumn{2}{|l|}{ Pagina } & \multirow{4}{*}{$\begin{array}{l}\text { Haduções omitem ou } \\
\text { sexuais, evitam falar }\end{array}$} \\
\hline h990zissão] tżytkować odpowiednio swego szczura & 239 & TAA & \\
\hline $\begin{array}{l}\text { ÖS exemplos demonstr } \\
\text { Eoê pode utilizar adequadamente seu rato } \\
\text { Edepois tomam de Auguntote }\end{array}$ & \multirow{2}{*}{\multicolumn{2}{|c|}{ 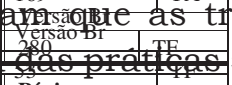 }} & \\
\hline Trepa com esse ratag. & & & \\
\hline ABGade.Codtriaduses, nos i jezbk i skastrowat go. & \multicolumn{2}{|c|}{ 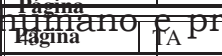 } & Epcuram abolir o uso \\
\hline 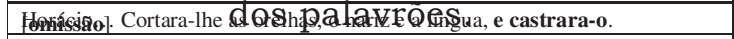 & N'srsão Br & $\mathrm{TA}$ & \\
\hline 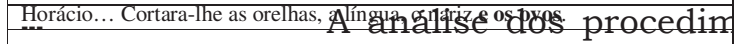 & \multicolumn{2}{|c|}{ 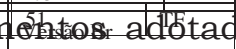 } & dos na tradução dos \\
\hline 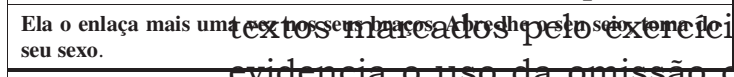 & \multicolumn{3}{|c|}{ iosela sexu列idade infantil e adulta } \\
\hline Seara vermalha & \multirow{3}{*}{\multicolumn{3}{|c|}{ 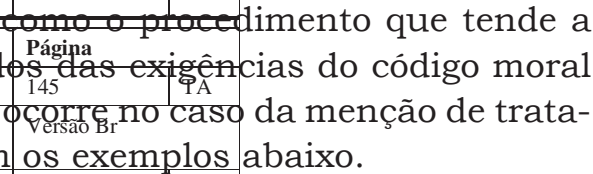 }} \\
\hline Kazat jej się rozebrać i pod pozorem badania obmacywat jej uda i piersi. & & & \\
\hline $\begin{array}{l}\text { Mandou que tirasse a roupe, a pretexto do exame, apapou suas coxsmeseus } \\
\text { seios. } \\
\text { mentos cruéis, como indicam }\end{array}$ & & & \\
\hline $\begin{array}{l}\text { Mandava que ela se desnudasse a pretexto do exame, apalpava nádegas e } \\
\text { seios. }\end{array}$ & \multicolumn{2}{|c|}{$\begin{array}{l}\text { Os exemplos } \\
152\end{array}$} & \\
\hline Gabriela cravo e canela & \multicolumn{2}{|l|}{ Página } & \\
\hline I dostat w gładkie liczko - Lowelas Toniczko. & 520 & TA & \\
\hline Esbofeteado o liso rostinho - de Lovelace Tonicozinho. & \multicolumn{2}{|l|}{ Versão Br } & \\
\hline O Tonico Pinico - Don Juan de puteiro - Se fudeu por inteiro. & 414 & $\mathrm{TF}$ & \\
\hline Tereza Batista cansada de guerra & \multicolumn{2}{|l|}{ Página } & \\
\hline Na wtasne oczy widziatem jednego z Guedesów w roli samicy. & 376 & TA & \\
\hline Vi com os próprios olhos um Guedes no papel de fêmea. & \multicolumn{2}{|l|}{ Versão $\mathrm{Br}$} & \\
\hline Vi com os meus olhos um Guedes sendo montado, servindo de mulher. & 304 & $\mathrm{TF}$ & \\
\hline
\end{tabular}


A tradução de $O$ cavaleiro da esperança omite a menção à tortura nas partes íntimas. A tradução de Terras do sem fim desvia a atenção do leitor de órgão sexual masculino recorrendo à explicação do ato de tortura, como castração.

O último romance de Jorge Amado traduzido para o polonês, editado após a queda do regime comunista, já parece tratar a questão da moral sexual de uma maneira mais aberta. A tradução de Dona Flor e seus dois maridos não apenas não omite as menções à sexualidade, mas, ao contrário, parece chamar a atenção do leitor para a esfera do erotismo, como demonstra o exemplo.

A qualificação do decote do personagem da mulata Dionísia de Oxossi como impudico pode ser vista como um juízo de valor negativo, acrescentado pela tradução polonesa ao texto brasileiro. Porém, avaliado no conjunto da tradução de Dona Flor e seus dois maridos, o acréscimo parece querer erotizar a cena em questão.

Além de regular as questões do comportamento sexual, o código moral comunista ajusta outro assunto, desta vez de ordem politica: a fidelidade incondicional ao aliado maior e, nos termos desta, a fidelidade aos interesses do próprio Estado, como ilustram os exemplos a seguir. 


\begin{abstract}
ABC de Castro Alves
Página

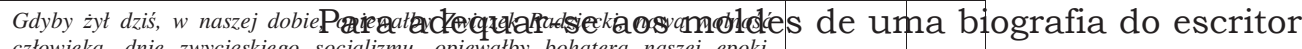

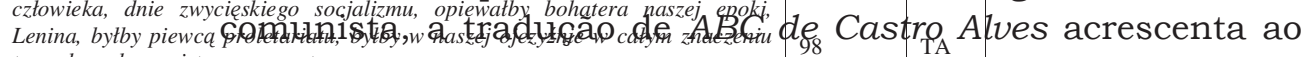
tego stowa komunistycznyzpgetas elogios ao aliado maior, a União Soviética com seus he-

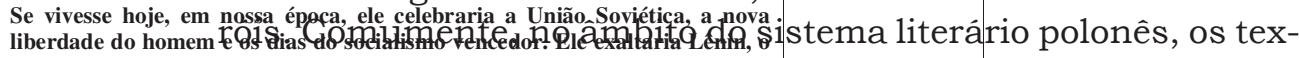

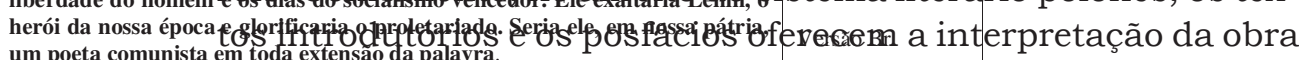

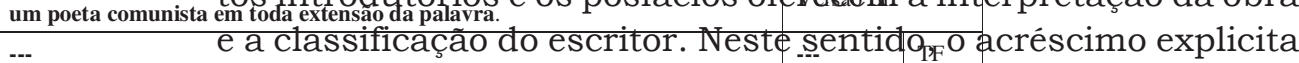
o mundo da paz O perfil moral que se espera do comuninista potonês: ele deve cele-

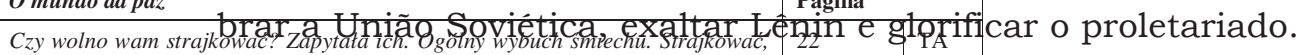
przeciw koти? Przeci@odrnomyaliado maior, a União Soviética também está isenta de

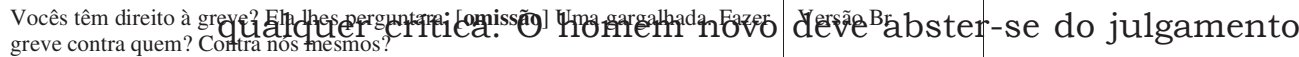
Ela lhes perguntara: doss rumps?

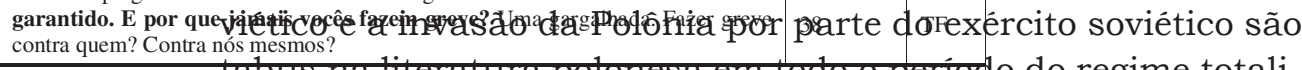

do regime totaliOs subterrâneos da liberdade
tarlo. A Omissão adotada na traduágina
Podnoszono wrzawe przeciw de

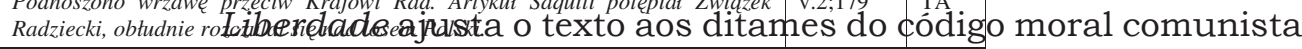

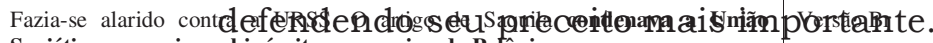

Soviética, comovia-se, hipócrita com a sina da Polônia.

Comentários sobre o pacto germano-soviético. Saquila escrevia soabre de O mundo da paz omite uma

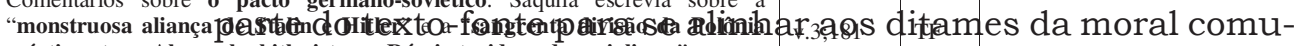
mártir entre a Alemanha hitlerista e a Rússia traidora do socialismo".
\end{abstract}


nista. Para o regime, é melhor não informar o trabalhador polonês sobre o privilégio do direito à greve, concedido, aparentemente, ao proletariado soviético. A omissão, nesse caso, corrobora o interesse dos governantes da Polônia. As greves dos trabalhadores poloneses foram combatidas com o uso das forças de repressão em todas as épocas do governo do regime comunista.

Considerando as questões centrais da moralidade comunista que se referem à sexualidade e à postura da fidelidade politica, os textos amadianos são alinhados às regras comportamentais vigentes na Polônia Popular, utilizando-se a tradução dos procedimentos tradutórios de omissão e de acréscimo. Essa tendência, porém, enfraquece no final dos anos oitenta com a abertura do sistema político polonês depois da queda do sistema comunista.

\section{Pilar do comunismo e escritor exótico!}

Decididamente "um pilar do comunismo" e, também, definitivamente, "um escritor exótico", respondem à pergunta que dá título ao presente artigo. A importação de Jorge Amado para o polissistema sociopolítico polonês objetivava a consolidação dos valores da ideologia comunista, assim como visava à diversificação do repertório do sistema literário da República Popular da Polônia.

O sistema literário polonês recorre à importação das obras do mega-sistema soviético da literatura e, nesse grupo, promove também as traduções da obra do escritor brasileiro Jorge Amado. As biografias do romancista brasileiro e as notícias a seu respeito veiculadas na imprensa polonesa, reforçam o ideal do escritor comunista comprometido com as diretrizes do PC. Os metatextos veiculados nos periódicos especializados enquadram a obra de Jorge Amado dentro das exigências do realismo socialista. As convicções políticas do próprio escritor, defendidas nos seus textos e comprovadas pela realização das tarefas outorgadas pelo partido, identificam Jorge Amado com o mega-sistema sociocultural soviético. As viagens do autor pela União Soviética e pelas Democracias Populares, assim como uma rede de rela-

TradTerm, 17, 2010, p. 127-156 
ções de amizade com os dirigentes da vida política e cultural desses países, colaboram para seu sucesso como escritor nos sistemas literários de todo o bloco comunista na época do stalinismo. Com o boom da literatura ibero-americana no sistema mundial de literatura, Jorge Amado recomeça a ser traduzido e editado na Polônia. Embora se abra para o exotismo e o sensualismo dos escritos do autor baiano, a imprensa polonesa, nessa época, continua a associar Jorge Amado à militância comunista.

Os resultados da análise das traduções evidenciam um grande interesse do sistema literário polonês pela obra de Jorge Amado. Um apreciável número dos livros traduzidos, sua tiragem grande e seu preço acessivel, bem como o volume considerável de resenhas críticas demonstram a predileção do sistema literário polonês pela produção literária do escritor brasileiro. Essa preferência demonstra-se fortemente marcada pela ideologia do regime nos anos de 1949 a 1957. Os críticos literários salientam o amadurecimento ideológico de Jorge Amado, enfatizando o realismo de suas obras. O naturalismo e o exotismo, presentes na obra amadiana, são ajustados aos ditames do discurso sobre a literatura. O sistema literário polonês retorna às traduções da obra de Amado nos anos de 1968 a 1993. Nessa época, os textos críticos sublinham um forte componente exótico presente na obra do escritor.

A conceituação da tradução por meio da análise dos textos amadianos editados na Polônia evidencia a presença de um forte componente ideológico que torna a tradução uma ferramenta a serviço do regime político. Por isso, a tradução é concebida como uma melhora do original, que permite interferências sobre o texto-fonte para moldá-lo de acordo com os imperativos do sistema sociopolítico da cultura-alvo. A tendência para a domesticação das traduções intensifica-se no período do realismo socialista visando sempre reforçar o discurso da propaganda partidária em vigor. O domínio da domesticação nas traduções polonesas da obra amadiana compreende o discurso sobre o aliado e sobre o inimigo politico, sobre a moral sexual e sobre os relacionamentos de homem e mulher, assim como sobre a relação com o catolicismo, todos eles campos relevantes para a ma- 
nutenção da hierarquia dos valores do comunismo. Já no final do período pesquisado acentua-se a presença da norma de estrangeirização. O domínio da estrangeirização abrange as categorias da designação dos personagens, da culinária e da representação das religiões de matrizes africanas e do espiritismo, que não possuem a força de contestação da hierarquia de valores constituintes da sociedade comunista.

Os textos importados do escritor brasileiro Jorge Amado constituem um dos pilares sobre as quais se apóia a construção da cosmovisão soviética no polissistema sociopolítico da República Popular da Polônia. A edificação dessa visão do mundo aproveita os elementos exóticos para fortalecer o aspecto universal da grande empreitada comunista.

\section{Referências Bibliográficas}

DAVIES, Norman (1981) God's Playground: A history of Poland. Oxford: Clarendon Press.

EVEN-ZOHAR, Itamar (1990) "Polysystem Studies". In: Poetics Today. Tel Aviv: The Porter Institute for Poetics and Semiotics, v. 11, n. 1.

GATTAI, Zélia (1987) Senhora dona do baile. $5^{a}$ ed. Rio de Janeiro: Record.

LAMBERT, José; VAN GORP, Hendrik (1985) "On Describing Translations". In: Theo Hermans (ed.). The Manipulation of Literature. Studies in Literary Translation. London/Sydney: Croom Helm.

PINKER, Steven (2004) Tábula rasa: a negação contemporânea da natureza humana. Tradução de Laura Teixeira Motta. São Paulo: Companhia das Letras.

ROBYNS, Clem (1994) “Translation and Discursive Identity”. In: Poetics Today. Tel Aviv: The Porter Institute for Poetics and Semiotics, v. 15, n. 3.

SIEKIERSKI, Stanisław (1992) Ksiażka literacka. Potrzeby społeczne $i$ ich realizacja $w$ latach 1944 - 1986. Warszawa: Wydawnictwo Naukowe PWN.

TOURY, Gideon (1995) Descriptive Translation Studies and Beyond. Amsterdam: John Benjamins. 